\title{
KLASIFIKASI POLA IMAGE PADA PASIEN TUMOR OTAK BERBASIS JARINGAN SYARAF TIRUAN ( STUDI KASUS PENANGANAN KURATIF PASIEN TUMOR OTAK )
}

\author{
Sri Heranurweni ${ }^{1)}$, Budiani Destyningtias ${ }^{2)}$, Andi Kurniawan Nugroho ${ }^{3)}$ \\ ${ }^{1,2,3}$ Teknik Elektro, Fakultas Teknik Universitas Semarang \\ heranur@usm.ac.id , destyningtias@usm.ac.id, andikn@usm.ac.id
}

\begin{abstract}
Abstrak - Saat ini ilmu kedokteran telah berkembang pesat, teknik diagnostik dan pengobatan telah memberikan harapan hidup bagi pasien. Salah satu cara pemeriksanaan penderita tumor otak adalah Pemeriksaan radiologis yang perlu dilakukan antara lain MRI dengan kontras. Citra otak MRI berguna untuk melihat adanya tumor pada langkah awal penegakkan diagnosis dan sangat baik untuk melihat klasifikasi, lesi erosi/destruksi pada tulang tengkorak. Pengolahan citra smoothing, segmentasi dengan metode otsu dan ekstraksi ciri yang dilakukan untuk mempermudah proses pelatihan dan pengujian. Penelitian ini, akan menerapkan analisis tekstur dengan parameter contrast, correlation, energy, homogenity untuk membedakan tekstur citra tumor otak dan normal sehingga menghasilkan nilai gold standard berdasarkan ciri-ciri tekstur yang ada. Pelatihan dan pengujian fiturfitur tekstur menggunakan metode propagasi balik (backpropagation) jaringan syaraf tiruan dengan variasi nilai learning rate sehingga diharapkan dapat memperoleh klasifikasi dari kondisi citra penderita tumor otak. Data yang digunakan sejumlah 29 citra otak yang menghasilkan akurasi klasifikasi sebesar 96,55\%.
\end{abstract}

Kata kunci : citra MRI, tumor otak, tekstur, backprogation

Abstract - Nowadays medical science has developed rapidly, diagnostic and treatment techniques have provided life expectancy for patients. One way of examining brain tumor sufferers is radiological examination that needs to be done, including MRI with contrast. MRI brain images are useful for seeing tumors in the initial steps of diagnosis and are very good for classification, erosions / destruction lesions of the skull. Smoothing image processing, segmentation with otsu method and feature extraction are carried out to facilitate the training and testing process. This study, will apply texture analysis with the parameters contrast, correlation, energy, homogenity to distinguish the texture of brain tumor images and normal so as to produce a standard gold value based on existing texture characteristics. Training and testing of texture features using backpropagation method of artificial neural networks with variations in learning rate values so that it is expected to obtain a classification of the image conditions of patients with brain tumors. The data used are 29 brain images that produce classification accuracy of $96.55 \%$.

Keywords : MRI images, brain tumors, textur, backprogation

\section{PENDAhUluAN}

Tumor otak ini dapat berupa tumor yang sifatnya primer ataupun yang merupakan metastasis dari tumor pada organ tubuh lainnya. Tumor otak mempunyai sifat yang berlainan dibandingkan tumor di tempat lain, walaupun secara histologisnya jinak, akan bersifat menjadi ganas karena letaknya yang berdekatan atau berada di sekitar struktur vital dan dalam rongga tertutup yang sukar dicapai. Tumor otak merupakan tumor dengan tingkat keganasan kedua setelah tumor darah (leukemia). Penderita tumor otak di Indonesia semakin meningkat akhir- akhir ini. . Peningkatan prevalensi kasus tumor otak ini menunjukkan adanya ancaman serius bagi bangsa Indonesia. Tumor otak dapat mengakibatkan menurunnya kualitas hidup penderitanya, juga mengakibatkan beban sosial dan ekonomi bagi penderita dan keluarganya, masyarakat dan negara.

Salah satu cara untuk mendeteksi secara dini penyakit tumor otak ini adalah dengan melakukan pemeriksaan radiologis, pada pemeriksaan secara radiologis yang perlu dilakukan antara lain Computed Tomografi Scan (CT Scan) dengan kontras; Magnetic Resonance Imaging (MRI) dengan kontras, serta Positron Emission Tomography - Computed Tomography (PET CT scan) (atas indikasi).

Penelitian ini penting dilakukan karena hasil pengolahan citra MRI yang dibaca dengan benar dapat digunakan sebagai sarana deteksi dini terhadap penyakit tumor otak, serta memberikan kemudahan bagi tenaga medis dalam membaca hasil MRI sehingga kesalahan diagnosis secara minimal dapat dihindari. Penelitian ini dilakukan dengan beberapa kegiatan utama, yaitu: pada tahap awal penelitian akan dilakukan proses pengujian algoritma pra-pengolahan citra dengan metode kontras dan cerah serta filtering. Selanjutnya dilakukan analisis tekstur citra menggunakan bantuan software ImageJ, kemudian dilakukan proses ekstraksi ciri dan menentukan klasifikasi tumor otak dengan citra otak normal dengan jaringan syaraf tiruan.

\section{TUMOR OTAK}

\section{a) PenyebabTumor Otak}

Penyebab terjadinya tumor adalah faktor genetik. Adanya abnormalitas gen yang mengontrol pertumbuhan sel otak. Kelainan ini dapat disebabkan oleh kelainan yang langsung mengenai gen atau adanya gangguan pada kromosom yang dapat merubah fungsi dari gen itu sendiri. Beberapa penelitian menunjukkan bahwa paparan radiasi dan bahan kimia juga dapat meningkatkan kejadian timbulnya tumor. Kemungkinan paparan bahan-bahan tersebut dapat menyebabkan perubahan struktur dari gen.

Tingkatan tumor otak terbagi dari tingkat 1 hingga tingkat 4. Pengelompokan ini didasari oleh perilaku tumor itu sendiri, seperti lokasi tumbuhnya tumor, kecepatan pertumbuhan, dan cara penyebarannya. Tumor otak yang tergolong jinak dan tidak berpotensi ganas berada pada tingkat 1 dan 2 . Ciri-ciri tumor otak jinak adalah tumbuh secara terbatas, memiliki selubung, tidak menyebar dan jika dioperasi dapat dikeluarkan secara utuh sehingga dapat sembuh sempurna. Sedangkan pada tingkat 3 dan 4, biasanya sudah berpotensi menjadi kanker dan sering disebut sebagai tumor otak ganas atau kanker otak. Kanker atau tumor ganas adalah pertumbuhan sel/jaringan yang tidak terkendali, terus bertumbuh/bertambah dan immortal (tidak dapat mati). Sel kanker dapat menyusup ke jaringan sekitar dan 
dapat membentuk anak sebar. Tumor ganas atau kanker otak ini memiliki ciri-ciri dapat menyusup ke jaringan_ sekitarnya, dan sel kanker dapat ditemukan pada pertumbuhan tumor. [1]

\section{b) Gejala Tumor Otak}

Gejala tumor otak sangat beragam dan bergantung pada lokasi, ukuran, atau tingkat pertumbuhan tumor itu sendiri. Tumor otak yang tumbuh secara perlahan-lahan mungkin awalnya tidak menimbulkan gejala apa pun (sangat minim) dan gejala ini menyamarkan diri mereka seperti sakit kepala dan kelelahan.. Setelah beberapa lama, tumor akan memberi tekanan pada otak atau membuat sebagian fungsi otak tidak bisa berfungsi dengan baik, gejala akan mulai muncul.yang menyebabkan munculnya gejala seperti kejang-kejang dan sakit kepala. Tumor otak yang berada pada lokasi tertentu dapat mengganggu sistem kerja otak sehingga tidak berfungsi dengan benar.

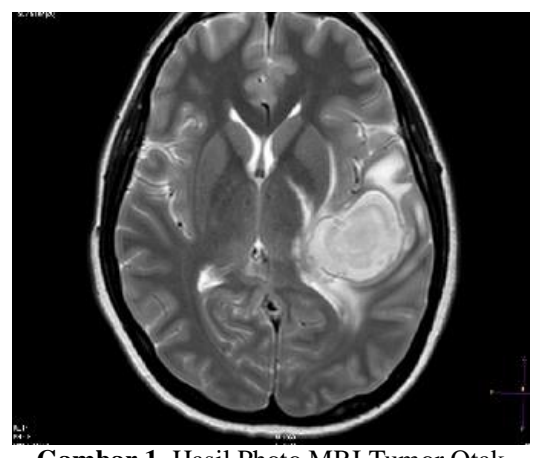

Gambar 1. Hasil Photo MRI Tumor Otak

\section{c) Penyebab Tumor Otak}

Sampai saat ini penyebab utama dari sebagian besar kasus tumor otak jinak masih belum diketahui. Belum diketahui secara pasti apa yang menyebabkan seseorang menderita tumor otak primer (tumor yang muncul pertama kali di otak atau jaringan sekitar otak). Diperkirakan bahwa tumor otak primer mulai muncul ketika sel normal mengalami kesalahan atau mutasi DNA. Mutasi inilah yang membuat sel-sel tumbuh dan berkembang biak dengan tingkat yang lebih cepat, serta tetap hidup ketika sel-sel sehat sudah mati. Akibatnya terjadi penumpukan sel-sel abnormal dan membentuk tumor. Terdapat beberapa faktor yang bisa meningkatkan risiko seseorang terkena tumor otak. Faktor keturunan dan juga efek samping prosedur radioterapi adalah dua di antaranya. Tumor otak primer lebih jarang terjadi dibandingkan tumor otak sekunder (tumor otak yang berasal dari kanker yang tumbuh di bagian tubuh lain lalu menyebar ke otak).

\section{Magnetic Resonance Imaging (MRI)}

Magnetic Resonance Imaging (MRI) merupakan suatu teknik penggambaran penampang tubuh berdasarkan perinsip resonansi magnetic inti atom hydrogen. Untuk mengetahui lebih lanjut, Magnetic Resonance Imaging (MRI) adalah suatu alat kedokteran di bidang pemeriksaan diagnostik radiologi, yang menghasilkan rekaman gambar potongan penampang tubuh / organ manusia dengan meng-gunakan medan magnet berkekuatan antara 0,064 $-1,5$ tesla ( 1 tesla $=1000$ Gauss) dan resonansi getaran terhadap inti atom hidrogen. Dasar dari pencitraan resonansi magnetik (MRI-Magnetic Resonance Imaging) adalah fenomena resonansi magnetik dari inti benda.

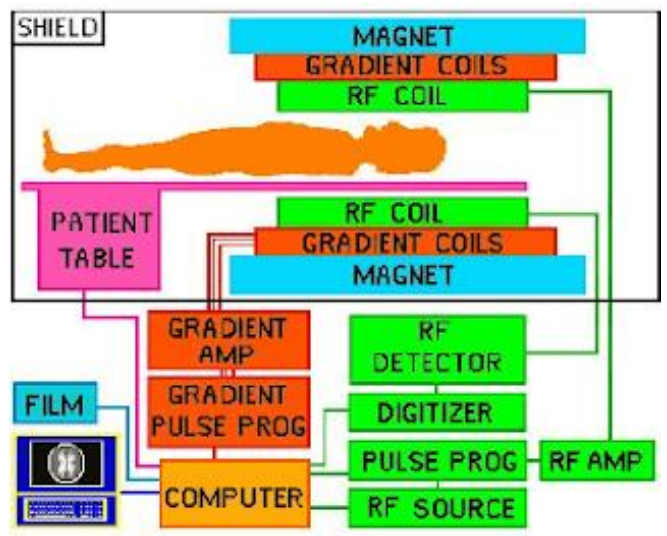

Gambar 2. Diagram Blok Proses MRI (Scott W, 2009)

Mengingat MRI bersifat non invasive, sehingga dalam pemeriksaan menggunakan MRI tidak menimbulkan rasa nyeri pada pasien serta dengan menggunakan MRI memberikan informasi yang baik keadaan jaringan lunak, hal tersebut disebabkan karena jaringan lunak yang terdapat dalam tubuh manusia sebagian besar terdiri dari air. Selain itu hasil pencitraan yang dihasilkan oleh MRI lebih jelas serta dapat dilihat dari berbagai sisi tanpa melibatkan pengunaan radiasi, memberikan hasil tanpa perlu mereposisi pasien, tidak menggunakan kontras untuk sebagian besar pemeriksaan MRI. Fasilitas MRI dilengkapi dengan kemampuan untuk menilai fungsi organ tertentu secara dinamik (Functional MRI), untuk menilai distribusi darah baik di otak maupun di jantung (Perfusion Imaging) serta melihat metabolisme yang ada didalam sebuah tumor (Spectroscopy Imaging).
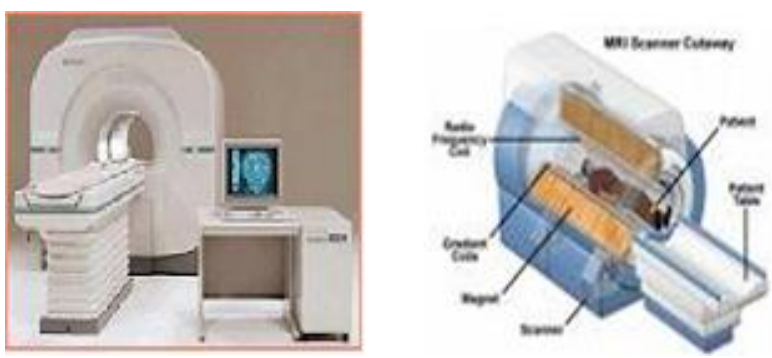

Gambar 3. Kiri: MRI, Kanan: Penampang MRI (Scott W, 2009)

\section{Sistem Klasifikasi Citra Tumor Otak}

Setelah citra MRI Tumor Otak didapat maka diubah terlebih dahulu dari citra berekstension DICOM ke dalam bentuk citra berekstension JPEG menggunakan software ImageJ, langkah selanjutnya adalah dilakukan pemrosesan citra dengan pre processing (pra pengolahan citra) ini adalah sebagai berikut Grayscale, pelembutan (smoothing) untuk menghilangkan noise (filtering), dan segmentasi. Tahapan yang dilakukan pada penelitian seperti pada gambar 4. berikut ini

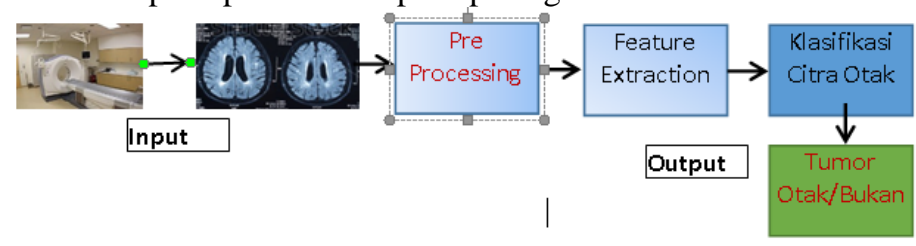

Gambar 4. Klasifikasi Citra MRI Tumor Otak dengan Backpropagation 


\section{Feature Extraction}

Feature Extraction atau ekstraksi fitur merupakan suatu pengambilan ciri / feature dari suatu bentuk dalam hal ini citra MRI tumor otak, nilai yang didaptkan akan dianalisis untuk proses peng-klasifikasian tumor otak menggunakan jaringan syaraf tiruan Backpropagation. Feature Extraction dilakukan dengan cara menghitung jumlah titik atau pixels yang ditemui dalam setiap pengecekan, dimana pengecekan dilakukan dalam berbagai tracing pengecekan pada koordinat kartesian dari citra input.

\section{Pengembangan Arsitektur Jaringan Syaraf Tiruan}

Jaringan Syaraf Tiruan yang digunakan dalam penelitian ini adalah Jaringan Syaraf Tiruan Multilayer. Algoritma yang digunakan dalam pembelajaran dan pengujian adalah Algoritma Backpropagation

\section{HASIL DAN PEMBAHASAN}

Data yang digunakan adalah data citra pasien tumor otak dan citra otak normal. Semua data dalam bentuk citra JPEG. Tahap pelatihan menggunakan 19 data citra otak, dengan 15 citra tumor otak, dan 4 citra otak normal. Tahap pengujian menggunakan 10 data citra otak dengan 8 citra tumor otak dan 2 citra otak normal.

Tahap ini mengolah citra otak setelah mengkonversi citra otak ke dalam bentuk citra berkestension JPEG. Setelah proses Grayscale yaitu mengubah citra otak ke dalam aras keabuan (untuk mempermudah proses pengolahan citra selanjutnya), dilanjutkan dengan penghilangan noise (filtering) dan proses segmentasi. Proses segmentasi ini menggunakan metode Threshold Otsu, karena metode ini yang paling baik hasilnya. Hasil dari segmentasi dilanjutkan dengan proses ekstraksi ciri. Ekstraksi ciri citra merupakan tahapan mengekstrak ciri atau informasi yang dimiliki oleh suatu objek dalam citra.

\section{a. Proses Pelatihan}

Proses pelatihan ini menggunakan jaringan syaraf tiruan propagasi balik (BackPropagation), dengan data pelatihan 19 citra. Citra yang digunakan merupakan hasil proses ekstraksi ciri. Tahap ini menggunakan parameter 100 epoch dan perhitungan erornya menggunakan MSE (Mean Square Error).

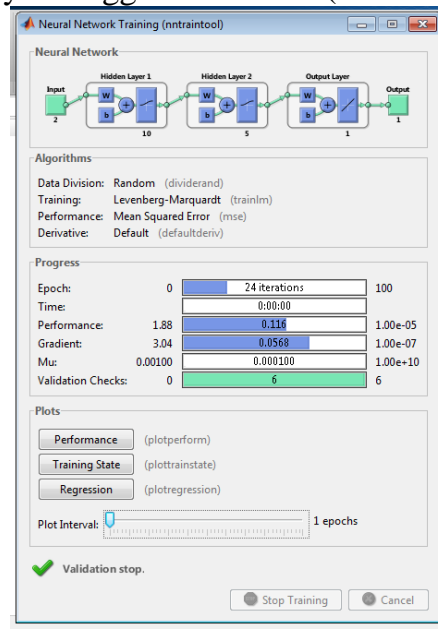

Gambar 5. Proses Pelatihan
Gambar 5. merupakan hasil proses pelatihan. Jaringan syarat tiruan ini mempunyai 2 lapisan input, 10 lapisan tersembunyi pertama, 5 lapisan tersembunyi kedua dan 1 lapisan output.

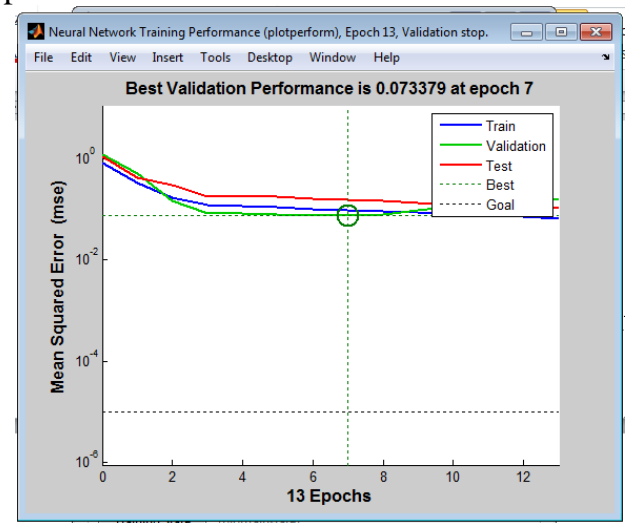

Gambar 6. Nilai Validasi Terbaik saat Pelatihan

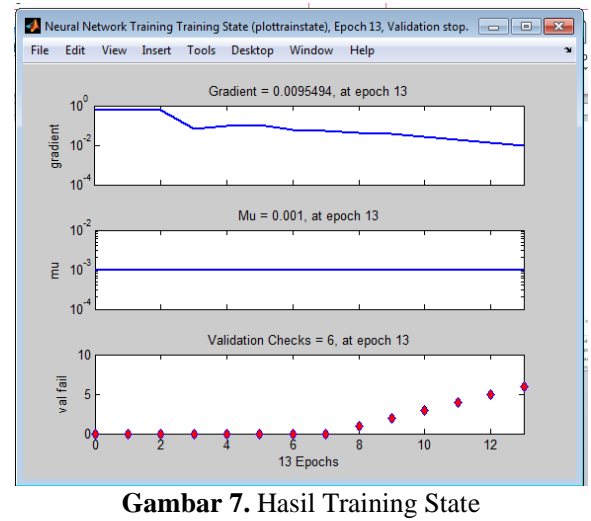

Kondisi terbaik saat pelatihan diperoleh pada epoh ke tujuh dengan nilai 0,0733 ,

\section{b. Proses Pengujian}

Proses pengujian ini menggunakan jaringan syaraf tiruan propagasi balik (BackPropagation), dengan data pengujian 10 citra. Citra untuk pembanding dari tahap pelatihan. Tahap ini menggunakan parameter 100 epoh dan perhitungan erornya menggunakan MSE (Mean Square Error). Gambar 5.6. merupakan hasil proses klasifikasi. Hasil klasifikasi ini dari 29 data citra otak dengan 23 citra tumor otak dan 6 citra otak normal, menghasilkan akurasi 96,55\%.

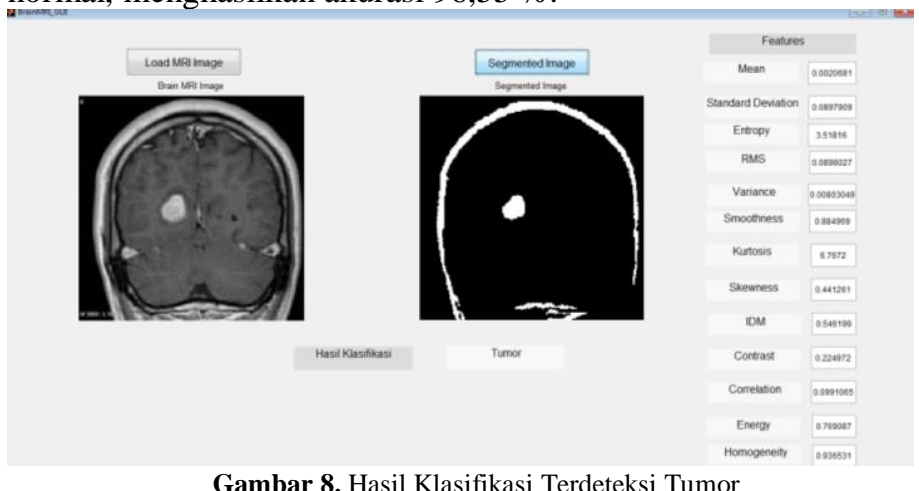

Gambar 8. Hasil Klasifikasi Terdeteksi Tumor 


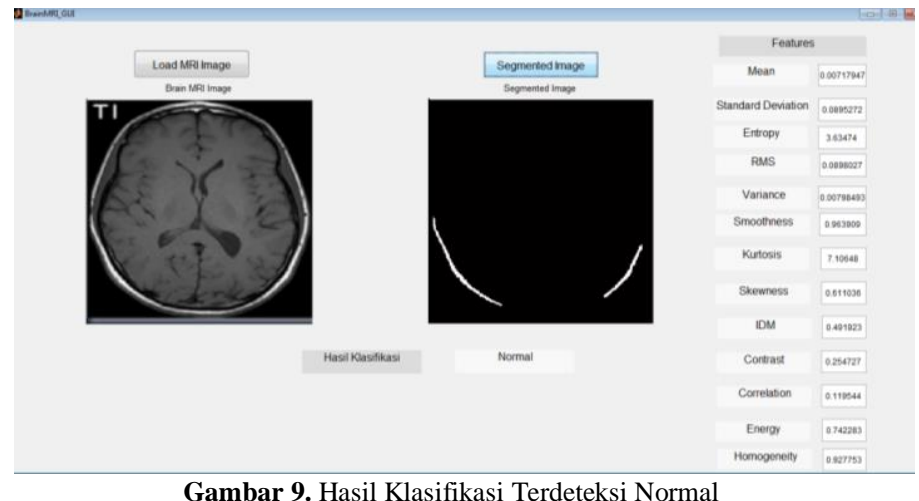

Gambar 9. Hasil Klasifikasi Terdeteksi Normal

\section{KESIMPULAN}

Proses pengolahan citra menggunakan proses smoothing untuk menghilangkan noise, metode otsu untuk segmentasi, dan ekstraksi ciri untuk mempermudah proses pada pelatihan dan pengujian. Parameter dari ekstraksi ciri yang digunakan adalah mean, standard deviation, entropy, RMS (Root Mean Square), variance, smoothness, kurtosis, skewness, IDM (Inverse Difference Movement), kontras, korelasi, energi dan homogenitas. Hasil klasifikasi menggunakan jaringan syaraf tiruan propagasi balik (Backpropagation) dengan 29 data citra otak dengan 23 citra otak normal dan 6 citra otak normal menghasilkan akurasi sebesar 96,55\%.

\section{DAFTAR PUSTAKA}

(1) Agung Adinegoro, Ratri Dwi Atmaja, Rita Purnamasari, 2105, Deteksi Tumor Otak dengan Ektrasi Ciri \& Feature Selection mengunakan Linear Discriminant Analysis (LDA) dan Support Vector Machine (SVM, e-Proceeding of Engineering : Vol.2, No.2 Agustus 2015, Page 2532 ISSN 2355-9365

(2) Modul Hematologi Onkologi, HO15_Tumor-Otak, http://spesialis1.ika.fk.unair.ac.id/download diakses tanggal 12 Juli 2018

(3) Russell, Norvig, 2010, Artificial Intelligence: A Modern Approach, 3rd ed, New Jersey, Prentice Hall

(4) Scott W. Atlas, MD, 2009, Magnetic Resonance Imaging of the Brain and Spine Volume Two $4^{\text {th }}$ Edition, Lipincot Williams \& Wilkins, California

(5) Y. Zhang, L. Wu, and S. Wang, 2011, Magnetic Resonance Brain Image Classification By An Improved Artificial Bee Colony Algorith, Progress In Electromagnetics Research, Vol. 116, 65-79

(6) Y. Zhang, L. Wu, 2012, An Mr Brain Images Classifier Via Principal Component Analysis And Kernel Support Vector Machine, Progress In Electromagnetics Research, Vol. 130, 369-388

(7) Y. Zhang, L. Wu, An Mr Brain Images Classifier Via Principal Component Analysis And Kernel Support Vector Machine, Progress In Electromagnetics Research, Vol. 130, 369-388
(8) Yeni Lestari Nst, Mesran, Suginam, Fadlina, 2017, Sistem Pakar Untuk Mendiagnosis Penyakit Tumor Otak Menggunakan Metode Certainty Factor (CF), Jurnal INFOTEK, Vol 2, No 1, Februari 2017 hal 8286 ISSN 2502-6968 (Media Cetak)

(9) Vinny Maritaa, Nurhasanaha, Iklas Sanubarya, tahun 2014 meneliti tentang Identifikasi Tumor Otak Menggunakan Jaringan Syaraf Tiruan Propagasi Balik pada Citra CT-Scan Otak, PRISMA FISIKA, Vol. V, No. 3 (2014), Hal. 117-121, ISSN : 23378204 